\title{
Identification of Biomphalaria havanensis and Biomphalaria obstructa Populations from Cuba Using Polymerase Chain Reaction and Restriction Fragment Length Polymorphism of the Ribosomal RNA Intergenic Spacer
}

\author{
Teofânia HDA Vidigal/*, Roberta L Caldeira*, Andrew JG Simpson**, \\ Omar S Carvalho*/+
}

\begin{abstract}
Departamento de Zoologia, UFMG, Belo Horizonte, MG, Brasil *Centro de Pesquisas René Rachou-Fiocruz, Av. Augusto de Lima 1715, 30190-002 Belo Horizonte, MG, Brasil **Instituto Ludwig de Pesquisas sobre o

Câncer, São Paulo, SP, Brasil
\end{abstract}

In Cuba, several Biomphalaria species have been reported such as B. orbignyi, B. schrammi, B. helophila, B. havanensis and B. peregrina; only the latter three are considered as potential hosts of Schistosoma mansoni. The specific identification of Biomphalaria species is based on anatomical and morphological characters of genital organs and shells. The correct identification of these snails is complicated by the high variation in these characters, similarity among species and in some cases by the small size of the snails. In this paper, we reported the classical morphological identification, the use of PCR and RFLP analysis of the internal transcribed spacer region of the ribosomal RNA genes for molecular identification of seven snail populations from different localities in Cuba. Using morphological and molecular analysis, we showed that among the studied Cuban Biomphalaria populations only $\mathrm{B}$. havanensis and $\mathrm{B}$. obstructa species were found.

Key words: Biomphalaria havanensis - Biomphalaria obstructa - polymerase chain reaction internal transcribed spacer - ribosomal DNA - snails - Cuba

Schistosomiasis mansoni is endemic in several countries of the Americas and Africa (WHO 1993). Although the disease has not been reported in Cuba yet, one can mention some Biomphalaria species such as: B. orbignyi Paraense, $1975 \mathrm{~b}$, B. schrammi (Cross, 1864), B. helophila (Orbigny, 1835), $B$. havanensis (Pfeiffer, 1839), B. peregrina (Orbigny, 1835). The latter three species are considered as potential hosts of Schistosoma mansoni (Richards 1963, Paraense \& Corrêa 1973, Michelson 1976, Yong et al. 1984, 1989, Yong \& Perera 1989, Paraense 1996). B. obstructa was mentioned in Cuba by PAHO (1968), Malek (1985) and Yong et al. (1989), however, in such papers it is not possible to identify the authors who found, for the first time, B. obstructa in this country. This species was described by Morelet (1849) based on specimens from Isla del Carmen, State of Campeche, Mexico.

Work partially supported by Fapemig and Capes. ${ }^{+}$Corresponding author. Fax: +55-31-3295.3115. E-mail: omar@cpqrr.fiocruz.br

Received 7 July 2000

Accepted 20 December 2000
The correct identification of Biomphalaria snails is difficult because of the high variation in the anatomical and morphological characters and similarity among species (Paraense 1975a, Yong et al. 1991, 1995). The taxonomy of Cuban Biomphalaria species remains confused and the correct identification of $B$. havanensis is always in discussion. This species has been considered as very similar to $B$. obstructa, B. orbignyi (Yong et al. 1991, 1995) and Biomphalaria sp., recently mentioned in Cuba by Durand et al. (1998). Paraense and Deslandes (1957) reported that $B$. havanensis (identified as Taphius maya) is indistinguishable from $B$. peregrina by shell features, however they can be differentiated by the radular characteristic (Paraense 1966). B. peregrina and $B$. orbignyi are morphologically recognized as similar species also (Paraense 1975b, Yong \& Perera 1989, Yong et al. 1991).

Yong et al. (1991) and Durand et al. (1998) used multilocus enzyme electrophoresis to identify Cuban snails such as $B$. havanensis, $B$. orbignyi, B. helophila and Biomphalaria sp.

The polymerase chain reaction and restriction fragment length polymorphism ribosomal DNA internal trancribed spacer (rDNA-ITS) have been used in studies on identification of Biomphalaria 
species from South America (Vidigal et al. 1998, 2000, Caldeira et al. 1998, 2000, Spatz et al. 1999, 2000).

In the current study, we analyzed snail populations from seven different localities, in Cuba, using morphological and PCR-RFLP techniques and we also propose the use of this molecular method as an auxiliary tool to identify the Cuban Biomphalaria snails.

\section{MATERIALS AND METHODS}

Snails - Seven snails of Cuban populations from Canasi, Zanja Ferrer, Arroyo Arenas, Hanabanilla, Santa Rita, Guatao and Hanabanilla Vaqueria, maintained for six months, approximately, in the Department of Malacology of Pedro Kouri Institute, Havana, Cuba, were used.

Morphological identification and DNA extraction of the snails - Ten specimens of each population were killed and fixed (Paraense 1976). Before fixation, the foot of each specimen was removed for subsequent DNA extraction (Vidigal et al. 2000).

Following fixation, the specimens were identified according to Paraense and Deslandes (1958), and Paraense (1975a, 1990, 1996).

The PCR amplification and RFLP profile analysis - The entire ITS region (ITS1 + 5.8S + ITS2) of rDNA was amplified using the same primers and conditions used by Vidigal et al. (1998). The most effective enzymes used in our previous studies with Biomphalaria snails (Vidigal et al. 1998,
2000, Caldeira et al. 1998, 2000, Spatz et al. 1999, 2000) were used in this study: AluI, (New England Biolabs, USA) MnlI, DdeI and HaeIII, (Promega Co, USA). Digestion and RFLP analysis were performed as described by Vidigal et al. (1998).

\section{RESULTS}

Morphological identification - In six localities (Canasi, Arroyo Arenas, Hanabanilla, Santa Rita, Guatao, and Hanabanilla Vaqueria), the specimens were morphologically identified as $B$. havanensis. The specimens from Zanja Ferrer were identified as $B$. obstructa. In addition, snails previously characterized as $B$. obstructa from Isla del Carmen, Mexico (type locality) and two localities from Dominican Republic (Villa Vasquez and Santo Domingo), maintained in the Departments of Malacology of the Oswaldo Cruz Institute, Rio de Janeiro, and Pedro Kouri Institute, Havana, Cuba, respectively, were included in this study for morphological and molecular comparisons with snails from Cuba.

Comparison of the Biomphalaria rDNA-ITS RFLP profiles - PCR amplification of the ITS region of the snails resulted in a product of approximately $1.3 \mathrm{k}$ bp (data not shown). The DdeI (Fig. 1) produced a simple profile of three or five fragments for each specimen in which two fragments are present only in snails morphologically identified as B. obstructa (lanes 1, 6 to 9, and 30 to 36). Similar profiles obtained among the specimens from Zanja Ferrer, Cuba (lanes 6 to 9), Isla del

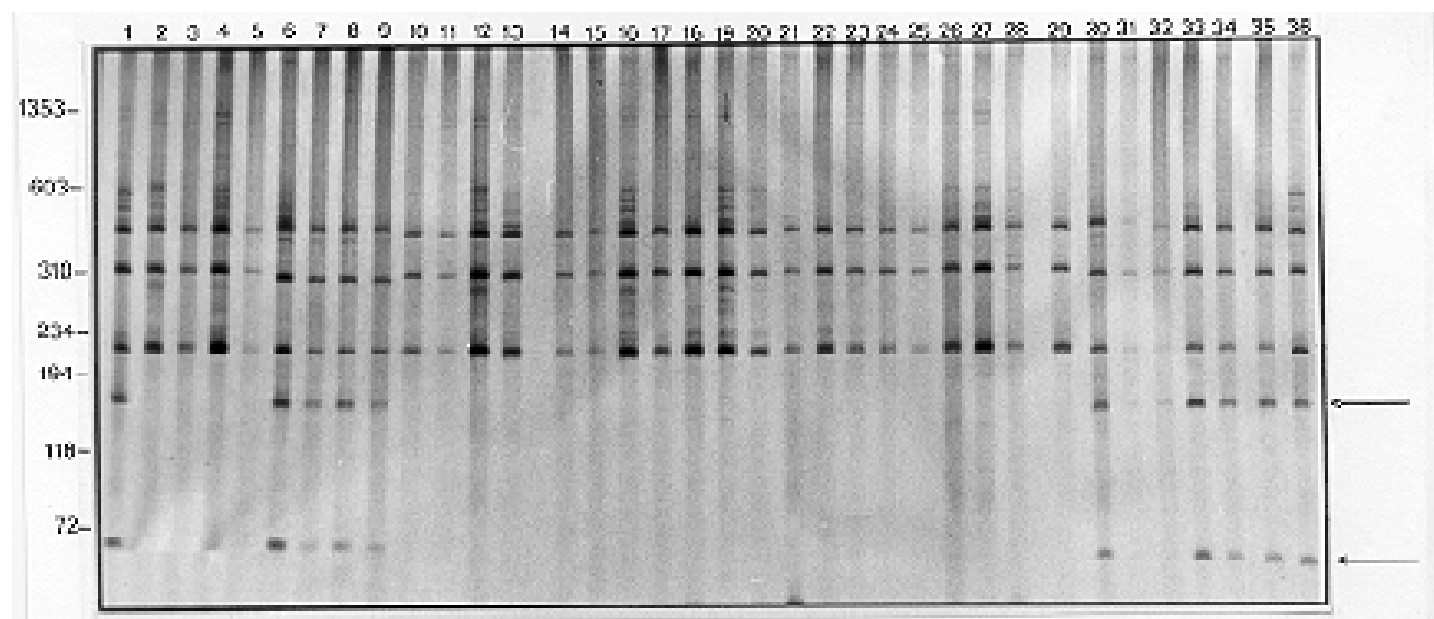

Fig.1: silver stained polyacrylamide gel $6 \%$ showing the PCR and RFLF profiles obtained following the digestion of the rDNA internal transcribed spacer region with DdeI. Lane 1: Biomphalaria obstructa from Isla del Carmen, México; lanes 2-5: B. havanensis from, Canasi, Cuba; lanes 6-9: B. obstructa from Zanja Ferrer, Cuba; lanes 10-13: B. havanensis from Arroyo Arenas, Cuba; lanes 14-17: B. havanensis from Hanabanilla, Cuba; lanes 18-21: B. havanensis from Santa Rita, Cuba; lanes 2225: B. havanensis from Guatao, Cuba; lanes 26-29: B. havanensis from Hanabanilla Vaqueria, Cuba; lanes 30-32: B. obstructa from Villa Varquez, Cuba; lanes 33-36: B. obstructa from Dominican Republic. Molecular size markers are shown on the left of each gel. The arrows indicate species specific fragments for B. obstructa. 
Carmen, Mexico (lane 1) and Dominican Republic (lanes 30 to 36) suggest that snails from Zanja Ferrer belong to $B$. obstructa species. The other Cuban snail populations from Canasi, Arroyo Arenas, Hanabanilla, Santa Rita, Guatao, Hanabanilla Vaqueria, identified by morphological methods as $B$. havanensis, were molecularly characterized by the presence of three fragments (Fig. 1, lanes 2 to 5 , and 10 to 29 ).

To confirm the molecular identification obtained with $D d e$ I enzyme, three other enzymes were tested using two specimens of each population. Figs 2A, B, C show, the rDNA-ITS RFLP profiles obtained with $A l u \mathrm{I}, M n l \mathrm{I}$ and HaeIII enzymes, respectively. The $A l u \mathrm{I}$ profiles were very similar for $B$. havanensis and $B$. obstructa, both with only one distinct fragment characterizing each species (Fig. 2A, lanes 1 to 5, B. obstructa; lanes 6 to $11, B$. havanensis). Two polymorphic profiles were obtained using the MnlI enzyme. However, both global profiles were very clear allowing to separate these two species (Fig. 2B). B. havanensis was characterized by the presence of two fragments (lanes 6 to 11) that permitted a clear distinction of such species from B. obstructa (lanes 1 to 5). The HaeIII showed RFLP profiles (Fig. 2C) which included two invariable profiles with species-specific products for the two species. B. obstructa snails (lanes 1 to 5 ) showed distinct profiles from $B$. havanensis which exhibited one clear profile with five fragments (6 to 11). Comparing the products obtained with all enzymes (DdeI, AluI, MnlI and Hae III) for snails from Zanja Ferrer (Cuba) with the ones obtained for $B$. obstructa, from Isla del Carmen and Dominican Republic, it was possible to conclude that these populations belong to the same species.

\section{DISCUSSION}

The molecular techniques based on PCR-RFLP analysis of the rDNA ITS region have been extensively used for many analyses of schistosomiasis intermediate host of the genera Bulinus, Oncomelania and Biomphalaria (Hope \& McManus 1994, Vidigal et al. 1998, 2000, Caldeira et al. 1998, 2000, Jones et al. 1999, Spatz et al. 1999, 2000). In Cuba, malacological surveys have been considered very important to better know the geographical distribution and also to help the health institution programs, in order to prevent the introduction of schistosomiasis in the country. Yong et al. (1997) discussed about the type locality of $B$. havanensis suggesting that specimens described by Paraense and Deslandes (1958), as B. havanensis (collected in the Country Club of Havana), may in fact belong to another species. The first authors suggest that the Country Club of Havana species does not correspond to the type locality of $B$. havanensis. In previous studies, $B$. havanensis has been mentioned as very similar to $B$. obstructa, $B$. orbignyi (Yong \& Perera 1989, Yong et al. 1995) and $B$. peregrina (Yong et al. 1989) based on their shell

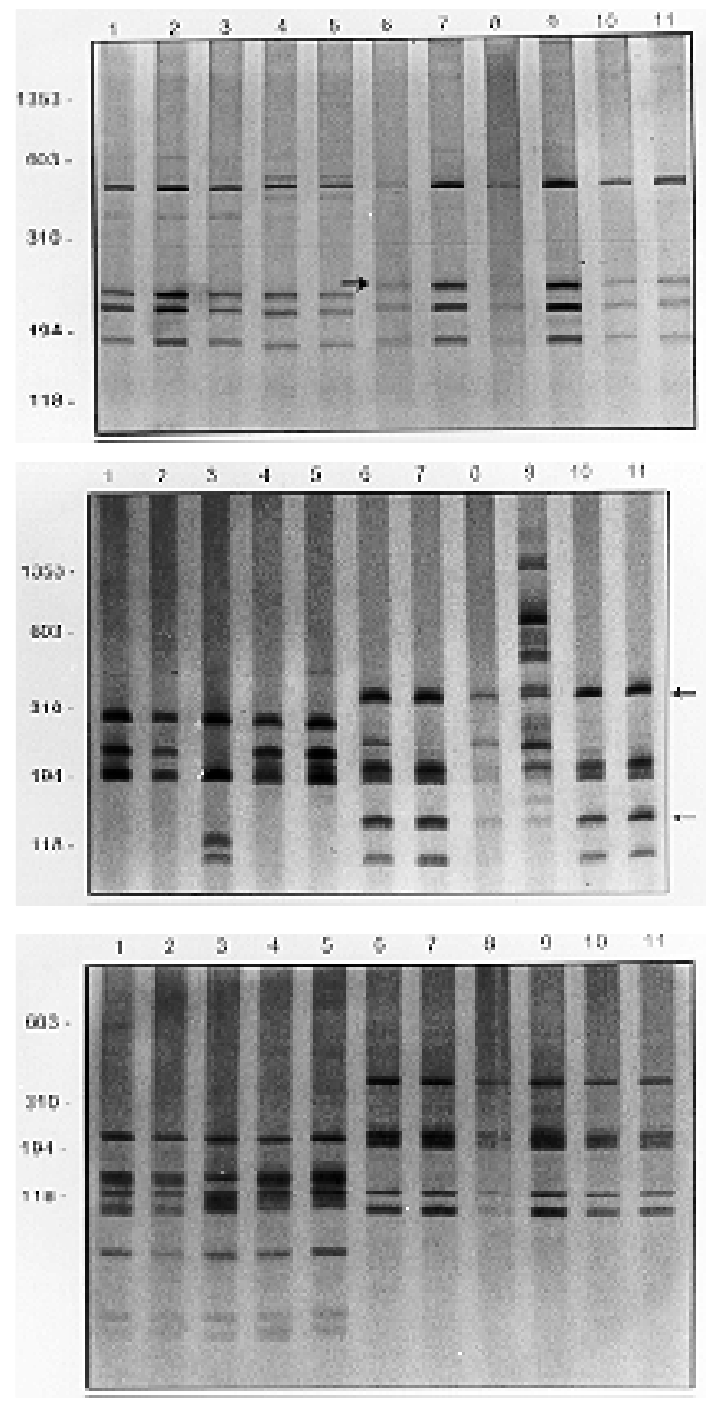

Fig. 2: silver stained polyacrylamide gels $6 \%$ or $8 \%$ showing the PCR and RFLP profiles obtained following the digestion of the rDNA internal transcribed spacer region with $A l u \mathrm{I}(\mathrm{A})$, MnlI (B) and HaeIII (C). In each gel the snails specimens are: lanes 1-2: Biomphalaria obstructa from Isla del Carmen, México; lane 3: B. obstructa from Santo Domingo, Dominican Republic; lane 4: B. obstructa from Zanja Ferrer, Cuba; lane 5: B. obstructa from Villa Vasquez, Dominican Republic; lane 6: B. havanensis from Canasi, Cuba; lane 7: B. havanensis from Arroyo Arenas, Cuba; lane 8: B. havanensis from Hanabanilla, Cuba; lane 9: B. havanensis from Santa Rita, Cuba; lane 10: B. havanensis from Guatao, Cuba; lane 11: $B$. havanensis from Hanabanilla Vaqueria, Cuba. Molecular size markers are shown on the left of each gel. The arrows in A and $\mathrm{B}$ indicate species specific fragments for B. havanensis. 
characteristics. The identification of these species is very important because $B$. obstructa and $B$. orbignyi have been considered refractory to infection by $S$. mansoni (Richards 1963, Paraense 1975b, Sullivan \& Hu 1996), whereas B. havanensis is considered as a potential intermediate host (Richard 1963, Michelson 1976). The latter species is considered widely spread in Cuba (Yong et. al. 1995) and has also been found in Antillean region, Mexico, Central America and probably in some localities of northern South America (Malek 1985). B. orbignyi had been previously found only in Argentina (Paraense 1975b) and, recently, in Cuba (Yong \& Perera 1989). This species is morphologically very similar to $B$. peregrina, which is one of the most widespread planorbid species in the Neotropical region and a potential intermediate host of $S$. mansoni (Paraense 1966, 1975a, Paraense \& Corrêa 1973). Recently, Spatz et al. (2000), using PCR-RFLP, showed that it is possible to separate $B$. havanensis from $B$. peregrina and $B$. orbignyi.

B. obstructa occurs in regions of the gulf coastal of the United States, Caribbean and Mexico (Malek 1985). However, since 1995, Yong et al. considered B. obstructa as "nomina spurea" [sic]. According to Yong (1998) the topotypic B. obstructa, reviewed by Paraense (1990), would correspond perfectly to the topotypic $B$. havanensis and would be a synonym of the latter.

In spite of the important questions on $B$. obstructa (Yong 1998) and the type locality of $B$. havanensis (Yong et al. 1997), in the present work, the Cuban snail populations were identified in accordance with the classical morphological systematics adopted by Paraense, which has produced the most complete description of the majority of the Neotropical Biomphalaria species (Paraense 1975a,b, 1990, 1996, Paraense et al. 1992).

As a result of our current analysis, two clear profiles were obtained with $D d e I$ enzyme, identifying two species as shown by morphological criteria. The profiles among specimens from different areas were highly reproducible.

The products obtained with $A l u \mathrm{I}, \mathrm{Mnl \textrm {I }}$ and HaeIII confirmed morphological data and reinforced the molecular results provided by $D d e I$ enzyme. The observation of two profiles for all analyzed snails demonstrated that among those populations only $B$. havanensis (Canasi, Arroyo Arenas, Hanabanilla, Santa Rita, Guatao, and Hanabanilla Vaqueria) and B. obstructa (Zanja Ferrer) species were found. Therefore, it is important to mention that (a) Zanja Ferrer and Calle Pila have recently been reported as type localities of B. havanensis (Yong et al. 1997), (b) Yong (1998) and Durand et al. (1998) reported the presence of Biomphalaria sp. in Canasi, Arroyo
Arenas, Santa Rita, Guatao, and Hanabanilla, and (c) B. peregrina has also been reported in Hanabanilla (Yong et al. 1989).

We showed that PCR-RFLP of the Biomphalaria rDNA ITS region, using DdeI, HaeIII, $M n l \mathrm{I}$ or $A l u \mathrm{I}$ enzymes allowed the differentiation of two Cuban Biomphalaria species. Such molecular data were supported by classical systematics of Paraense and Deslandes (1958) and Paraense (1990).

As already pointed out, PCR-RFLP methodology has the advantage of producing simple profiles for each species and also shows to be helpful in Cuban snail systematics.

\section{ACKNOWLEDGEMENTS}

To Dr Wladimir Lobato Paraense and Dr Lygia Corrêa, Departamento de Malacologia, Instituto Oswaldo Cruz, for supplying B. obstructa snails from Isla del Carmen, Mexico. To Dr Mary Yong and Dr Gloria Perera (in memoriam) for supplying the Cuban specimens. To Dr Wladimir Lobato Paraense and Dr Linus Spatz for assistance in morphological identification of Biomphalaria snails. To Dr Naftale Katz, Dr Wladimir Lobato Paraense and Dr Alejandra Rumi who provided valuable critical comments.

\section{REFERENCES}

Caldeira RI, Vidigal THDA, Paulinelli ST, Simpson AJG, Carvalho OS 1998. Molecular identification of similar species of the genus Biomphalaria (Mollusca: Planorbidae) determined by a PCR-RFLP. Mem Inst Oswaldo Cruz 93: 219-225.

Caldeira RL, Vidigal THDA, Matinella L, Simpson AJG, Carvalho OS 2000. Identification of Planorbids from Venezuela by polymerase chain reaction amplification and restriction fragment length polymorphism (PCR-RFLP). Mem Inst Oswaldo Cruz 95: 171-177.

Durand P, Yong M, Perera G, Decreux A, Pointier JP 1998. Genetic evidence of two species in the Biomphalaria havanensis complex (Gastropoda: Planorbidae) from Cuba. Acta Trop 71: 179-188

Hope M, McManus DP 1994. Genetic variations in geographically isolated populations and subspecies of Oncomelania hupensis determined by a PCR-based RFLP method. Acta Trop 57: 75-82.

Jones CS, Noble LR, Ouma J, Kariuli HC, Mimpfoundi R, Brown DS, Rollinson D 1999. Molecular identification of schistosome intermediate hosts: case studies of Bulinus forskalli group species (Gastropoda: Planorbidae) from Central and East Africa. Biol J Linn Soc 68: 215-240.

Malek EA 1985. Snail Hosts of Schistosomiasis and other Snail-transmitted Diseases in Tropical America: A Manual, OPAS, WHO, Washington, 325 pp.

Michelson EA 1976. A potential intermediate host of Schistosoma mansoni from Haiti. J Parasitol 6: 648649.

Morelet A 1849. Testacea Novissima Insulae Cubanae et Americae Centralis, Par I.J.-B. Bailière, Paris, 31 pp. PAHO-Pan American Health Organization 1968. A 
guide for the identification of the snail intermediate hosts of schistosomiasis in the Americas. Scientific Publication no. 168, Washington, 122 pp.

Paraense WL 1966. The synonymy and distribution of Biomphalaria peregrina in the Neotropical region. Rev Bras Biol 26: 269-296.

Paraense WL 1975a. Estado atual da sistemática dos planorbídeos brasileiros. Arq Mus Nac Rio de Janeiro 55: 105-128.

Paraense WL 1975b. Biomphalaria orbignyi sp. n. from Argentina (Gastropoda: Basommatophora: Planorbidae). Rev Brasil Biol 35: 211-222.

Paraense WL 1976. A natural population of Helisoma duryi in Brazil. Malacology 15: 360-376.

Paraense WL 1990. Biomphalaria obstructa (Morelet, 1849): a study of topotypic specimens (Mollusca: Pulmonta: Planorbidae). Mem Inst Oswaldo Cruz 85: 391-399.

Paraense WL 1996. Neotropical planorbid snails with apertural lamellae. I. Biomphalaria helophila (Orbigny, 1835). Mem Inst Oswaldo Cruz 91: 177186.

Paraense WL, Corrêa L 1973. Susceptibility of Biomphalaria peregrina from Brazil and Ecuador to two strains of Schistosoma mansoni. Rev Inst Med Trop São Paulo 15: 127-130.

Paraense WL, Deslandes N 1957. Observations sur Taphius maya. J Conchyliol 97: 49-158.

Paraense WL, Deslandes N 1958. Observations on Taphius havanensis (Pulmonata: Planorbidae). Rev Bras Biol 18: 87-91.

Paraense WL, Pointier JP, Delay B, Pernot AF, Incani RN, Balzan C, Chrosciechowski P 1992. Biomphalaria prona (Gastropoda: Planorbidae): a morphological and biochemical study. Mem Inst Oswaldo Cruz 87: 171-179.

Richards CS 1963. Infectivity of Schistosoma mansoni for Puerto Rico mollusks, including a new potential intermediate host. Am J Trop Med Hyg 12: 26-33.

Spatz L, Vidigal, THDA, Caldeira RL, Dias Neto E, González Cappa SM, Carvalho OS 1999. Study of Biomphalaria tenagophila tenagophila, B. $t$. guaibensis and B. occidentalis by polymerase chain reaction amplification and restriction enzyme digestion of the ribosomal RNA intergenic spacer regions. J Moll Stud 65: 143-149.

Spatz L, Vidigal THDA, Silva, MCA, González Cappa
SM, Carvalho OS 2000. Characterization of Biomphalaria orbignyi, B. peregrina and B. oligoza by polymerase chain reaction and restriction enzyme digestion of the internal transcribed spacer region of the RNA ribosomal gene. Mem Inst Oswaldo Cruz 95: 807-814.

Sullivan JT, Hu PC 1996. Fate of Schistosoma mansoni in Biomphalaria obstructa. J Parasitol 82: 743-747.

Vidigal THDA, Caldeira RL, Simpson AJG, Carvalho OS 2000. Further studies on the molecular systematics of Biomphalaria snails from Brazil. Mem Inst Oswaldo Cruz 95: 57-66.

Vidigal THDA, Spatz L, Nunes ND, Simpson AJG, Carvalho OS, Dias Neto E 1998. Biomphalaria spp: identification of the intermediate snail hosts of Schistosoma mansoni by polymerase chain reaction amplification and restriction enzyme digestion of the ribosomal RNA gene intergenic spacer. Exp Parasitol 89: 180-187.

WHO-World Health Organization 1993. The control of schistosomiasis. Second report of the WHO expert committee. Technical Report Series 830, WHO, Geneva, 86 pp.

Yong MC 1998. Biosystématique des Mollusques d'Eau Douce d'Intérêt Médical et Vétérinaire de Cuba, Ministere de l'Education Nationale de la Recherche et de la Technologie, France, 104 pp.

Yong M, Perera G 1989. First record of Biomphalaria orbignyi in Cuba. Walkerana 3: 211-215.

Yong M, Hubendick B, Rodriguez JE, Perera G 1984. Biomphalaria schrammi in Cuba. Walkerana 2: 141144.

Yong M, Perera G, Lopes JRF 1991. Caracterizacion de Biomphalaria orbignyi Paraense, 1974, molusco de importância médico-epidemiológico recientemente reportado para Cuba. Rev Cubana Med Trop 43: 2125.

Yong M, Perera G, Gutierrez A 1995. Biomphalaria havanensis y Biomphalaria orbigny (Mollusca: Planorbidae): Dos especies en sinonimia? Rev Cubana Med Trop 47: 209-210.

Yong M, Perera G, Pointier JP 1989. Presence of Biomphalaria peregrina in Hanabanilla, Cuba. J Med App Malacol 1: 183-187.

Yong M, Pointier JP, Perera G 1997. The type locality of B. havanensis (Pfeiffer, 1839). Malacological Review 30: 115-117. 